\title{
To Fall by Ambition-Grímur Thorkelín and his Beowulf Edition
}

\author{
Magnús Fjalldal
}

Published online: 11 September 2007

(C) Springer Science+Business Media B.V. 2007

\begin{abstract}
Grímur Jónsson Thorkelín (1752-1829), the Icelandic first editor of the Beowulf manuscript, had an unusual career that explains much about his edition. Thorkelín's rise in the world of Danish scholarship was fast and culminated in a successful journey to Britain to look for documents relevant to Danish history. He returned with two transcripts of the hitherto neglected Beowulf manuscript, and upon his return, the position of Keeper of the Royal Privy Archives awaited him. But all was not as it seemed. Thorkelín was essentially a fraud as a scholar, a fact not lost on many of his contemporaries, and much of his advancement had been through ingratiation rather than scholarly achievement. Thorkelín was well aware that he might not have the ability to produce an edition from his transcripts, and for nearly 30 years he vacillated between caution and ambition. In the end, however, it became commonly known that he had invaluable historical materials in his possession, and then his hand was forced. The edition, when at long last it appeared in 1815, was a predictable disaster which exposed the editor for what he was and brought him misery rather than scholarly fame.
\end{abstract}

Amazingly little has been written about the life and career of Grímur Jónsson Thorkelín, the first editor of Beowulf, although the edition he produced has attracted constant scholarly attention since its publication in 1815. The reason for this shortage of biographical studies is probably lack of information; Thorkelín did not keep a journal, little was written about him by people who knew him during his lifetime, and, although he was an energetic letter writer and corresponded with a number of people, his letters only very rarely touch upon his scholarly work (such as his discovering, copying and editing of his Beowulf transcripts) and have hence not attracted much interest. This has meant that Thorkelín's edition has been discussed

\footnotetext{
M. Fjalldal ( $\bowtie)$

Department of English, Faculty of the Humanities, University of Iceland, Nýi gardur, Sudurgata, 101 Reykjavik, Iceland e-mail: mafja@hi.is
} 
for nearly two centuries almost as if the man who produced it never existed. The aim of this essay is to try to bring to light the relevant facts concerning Thorkelín's life and career-insofar as they can be established-and to explore how and to what extent these factors might have influenced the making of his Beowulf edition.

Grímur Jónsson Thorkelín was born out of wedlock in 1752 into (on his mother's side) a long line of prominent county magistrates. He was brought up by relatives and eventually adopted his great-grandfather's last name (Porkelsson) in a Latinised form as his own. He attended the Skálholt Bishopric School and excelled as a student there. In 1770 he was offered to continue his education in Copenhagen (then the capital of the Icelandic colony). Thorkelín accepted and made Denmark his home for the rest of his life. In 1773 he graduated from the Copenhagen Metropolitan School and entered the Law School of Copenhagen University from which he qualified 3 years later.

Along with his legal studies, Thorkelín also began to immerse himself in Old Norse texts, medieval canonical law in particular. In 1775, he edited The Canonical Laws of Bishop Porlákr (Kirkjuréttur Porláks biskups) and 2 years later The Canonical Laws of Bishop Árni (Kirkjuréttur Árna biskups)—both accompanied by Latin translations. In 1786 he oversaw the publication of a two-volume edition of documents preserved in the Arnamagnæan collection relating to matters concerning Denmark and Norway (then also a Danish colony). Further smaller editions, e.g. of individual Eddic poems and family sagas, also followed.

These scholarly efforts were in turn duly rewarded. In 1777 Thorkelín was appointed secretary to the newly established Arnamagnæan Commission; in 1780 he was employed as an assistant in the Royal Privy Archives; 3 years later he was granted the title of university professor (professor extraordinarius) and in 1784 promised the post of Keeper of the Royal Privy Archives when that position became vacant. Thorkelín had to wait 7 years to cash in on this promise, but all the same, his rise in the world of scholarship had so far been nothing less than spectacular. But all was not quite what it seemed as we shall later see.

Thorkelín must have realized that in order to make sure that the Danish authorities honoured their promise of making him Keeper of the Royal Privy Archives in the fullness of time, it was important that he show continuing progress as a young scholar, and what better way to achieve that than to go abroad and unearth hitherto undiscovered documents relating to the history of Denmark. This idea was undoubtedly inspired by the work of a former Keeper of the Royal Privy Archives, Jacob Langebek (1710-1775), who had travelled extensively throughout Sweden and the Baltic states and made copies of documents relevant to Danish history. These he then published in his own name as The Langebekske Diplomatarium. Now that materials from Denmark's neighbours to the East had been gathered, it was perfectly logical to turn one's sights on England, Scotland and Ireland.

With his connections at the Danish court and support from an impressive array of learned friends, Thorkelín does not appear to have had much difficulty in persuading the authorities of the necessity of this undertaking. He was granted a leave of absence on full pay from his post as assistant in the Royal Privy Archives and his position with the Arnamagnæan Commission and given a very generous 2 year travel allowance (later extended to nearly 5 years) from a special royal fund (Fonden ad usus 
publicos). ${ }^{1}$ But as Thorkelín was getting ready to set sail for Britain in 1786, scholars have wondered whether he already knew of the existence of the Beowulf manuscript or not. A Danish scholar, Jens Christoffersen, insists that he did. Christoffersen points out that Danish antiquarians such as Jakob Langebek and Peter Suhm were familiar with Humphrey Wanley's Catalogue of Anglo-Saxon Poetry from 1705, which listed the poem and transcribed a few lines of it (1-19 and 53-73). Interestingly enough it was Wanley's mistaken description of it as a story of Beowulf the Dane who fights Swedish princes that was bound to attract Danish interest and, according to Christoffersen, before he left, Thorkelín would have been certain that this poem must contain valuable information about the earliest history of Denmark. ${ }^{2}$

Other scholars who have addressed this question disagree. Thus for instance Kevin Kiernan, Robert Bjork and T. A. Shippey all insist that Thorkelín had no prior knowledge of the Beowulf manuscript until he stumbled on it in Wanley's Catalogue in October of 1786, 2 months after he had begun working in the British Museum. ${ }^{3}$ There is, however, no real evidence to substantiate either claim. A letter from Thorkelín to his friend and benefactor Johan v. Bülow, dated November 3,1786, in which he mentions his discovery of the poem (to which he refers as a collection of songs about the achievements of Danish kings in the third century), gives no hint about the circumstances of his discovery. ${ }^{4}$ On the whole, Thorkelín's mission to Britain appears to have been something of a wild goosechase after Danish medieval heroes, and it is perhaps of little consequence whether he knew of the existence of the Beowulf manuscript or not before he left for Britain.

Thorkelín is often credited with having found and even rescued the Beowulf manuscript ${ }^{5}$ - which of course is sheer nonsense-as the manuscript was safely lodged in the British Museum. His real achievement was of an entirely different nature, namely producing the two transcripts of the poem from a manuscript which was gradually deteriorating and introducing this almost entirely neglected work to the scholarly world with his edition in 1815 . It is also quite clear from his abovementioned letter to Bülow that Thorkelín knew that he had found something important, even if he appears to have misunderstood the subject matter of Beowulf to begin with. Nearly three decades later, he reiterated this by-gone sense of achievement in his "Greetings to the Reader" with which he prefaced his 1815 edition: "I came home with great success and rich reward, and with me a poem that had been absent for more than a thousand years returned to its country of origin., 6

But let us now turn to the character of this successful young man, insofar as the available materials allow us to determine what he was like. First there is the small matter of his nationality. Thorkelín is of course usually identified as an

\footnotetext{
${ }^{1}$ See Kristjánsson (1999), p. 29.

2 Christoffersen (1946), p. 19.

${ }^{3}$ See Kiernan (1995), p. 196; Bjork (1996), p. 291; Shippey and Haarder (1998), p. 6.

${ }^{4}$ See Glahn (1925), p. 57.

${ }^{5}$ See e.g., Glahn (1925), p. 50; Christoffersen (1946), p. 20 and Ólason (1949), p. 107.

${ }^{6}$ Quoted from Bjork (1996), p. 301.
} 
Icelander by those who see fit to mention him or his edition, ${ }^{7}$ but this would not have pleased him much while he was alive. He thought of himself as a bona fide Dane, and seldom, if ever, has an Icelander appeared to have been more ashamed of his real nationality. This is quite clear from his correspondence with Johan v. Bülow, where references to himself as a Dane, his beloved Denmark and the dear land of "our" fathers crop up at regular intervals. ${ }^{8}$ It is therefore not surprising that Icelanders in Copenhagen-particularly those of the younger generation-did not want to associate with him, ${ }^{9}$ but Thorkelín does not seem to have cared; he was more interested in the company of a better class of people than his uncouth countrymen.

As I shall come back to later, Grímur Thorkelín was for all his success and learning rather lacking in some of the basic qualities that make a good scholarmostly in the sense that he could be very gullible and often seemed to lack common sense in his scholarly work. But these deficiencies he had so far been able to gloss over with his good looks, genteel manner and an unsurpassed ability to ingratiate himself with people in high places. ${ }^{10}$ E. C. Werlauff (1781-1871), who was a leading historian and librarian himself and seems to have known Thorkelín quite well, notes in his memoirs that in Denmark Thorkelín concentrated on winning favour among medieval historians and other antiquarians in the academic community, as well as with high-ranking civil servants. Only the highest-ranking Icelander in Copenhagen at the time, Jón Eiríksson, the head of the Royal Library, was, according to Werlauff, immune to Thorkelín's flattery and disliked him. ${ }^{11}$

While in Britain, Thorkelín spent at least as much time ingratiating himself with people in high places as he ever did looking for Danish-related documents. His Fragments of English and Irish History in the Ninth and the Tenth Century (written in 1788) targets Lord Francis Rawdon, Marquess of Hastings, with a page-long dedication of embarrassing flattery. Soon after his arrival in Britain he was socializing with members of the Royal Society and luminaries like Horace Walpole. ${ }^{12}$ But the highlight of this well-organized social climbing must have been Thorkelín's audience with the royal couple. ${ }^{13}$ And, as before, Thorkelín's efforts did not go unrewarded. In May of 1790 he could write to his friend Bülow that none other than the Archbishop of Canterbury had offered him a position with the British Museum; an honour that he had unfortunately had to decline because of the love and gratitude he felt towards his native country, Denmark, and her King and Crown Prince. ${ }^{14}$

This rather extreme devotion to royalty was probably quite heart-felt on Thorkelín's part. His correspondence with Bülow reveals fascination with the King

\footnotetext{
7 This, however, is not without exception. See e.g., Birrell (1966), p. 112 where Birrell refers to Thorkelín as a Dane.

8 See e.g., Glahn (1925), p. 60, 61, 66, 77 and 78.

9 See Kristjánsson (1999), pp. 33-34; Werlauff (1910), p. 123.

10 See e.g., Kristjánsson (1999), p. 28; Werlauff (1910), p. 121 and Christoffersen, (1946), p. 25.

11 Werlauff (1910), pp. 121-123.

12 See Bjork (1996), p. 293.

13 See Kristjánsson (1999), p. 30.

14 Glahn (1925), pp. 76-78.
} 
and the Crown Prince of Denmark that at times borders on obsession. ${ }^{15}$ This worship of Danish royalty is, however, somewhat difficult to fathom as the king, Christian VII, was not only mentally insane, but also scandalously debauched in his behaviour, and his only son, the future Frederik VI, who had been prince regent since 1784 , was indeed liberal but still untried as a ruler. ${ }^{16}$

In 1791 Thorkelín gave vent to his worship of Danish royalty by publishing an encomium about the prince regent (then only 23 years of age) titled: Sketch of the Character of his Royal Highness the Prince of Denmark to which is added a Short Review of the Present State of Literature and the Polite Arts in that Country; Interspersed with Anecdotes/in Four Letters by a Gentleman Long Resident in Copenhagen to a Friend in London. The purpose of this singular piece of work, however, was probably a bit more self-serving than just to provide an English friend with information about the prince regent. Thorkelín in effect produces a latter day saint's life in which the prince's perfection in every respect supplants the miracles. Thus the future Frederik VI is a champion of the freedom of the press (in a country that was still an absolute monarchy), has a keen interest in the rights of man, is hard working, devoid of snobbery, modest, kind and generous - to name only a few of the qualities with which Thorkelín invests him. The remainder of the book sings the praises of important people in academia and at the Arnamagnæan Commission. Two years later the book had been translated into Danish, and according to N. M. Petersen, a leading Danish 19th century literary historian, it effectively established Thorkelín's reputation in Denmark. ${ }^{17}$ In his Beowulf edition-as we shall later see-Thorkelín would return to his favourite subject of praising Danish royalty in a way that is difficult to understand unless the reader is aware of his previous fascination with Danish kings.

In his scholarly undertakings, which were mostly editions, Thorkelín has been characterised as incompetent. ${ }^{18}$ However, he could partly hide behind the fact that the more rigorous critical standards that 19 th century philologists adopted in their work had not become the norm for much of his career, and critical reviews of scholarly editions were only sporadic. He was, for instance, probably lucky that his Fragments of English and Irish History in the Ninth and the Tenth Century-in which he accepts a legendary, heroic-mythic saga (Ragnars saga loðbrokar ok sona hans) as the basis of the history of Northumbria in the 9th century-went unnoticed. Still, one of his saga editions, Eyrbyggja saga (1787) and his new translation of the

\footnotetext{
15 See e.g., Glahn (1925), p. 81 ("our most precious Crown Prince") and 82 ("the holy word of King and the Crown Prince"' [i.e. the promise of Thorkelín's becoming Keeper of the Royal Privy Archives]).

${ }^{16}$ Frederik VI did, however, turn out to be one of the more unfortunate kings of Denmark, as he first attempted to be neutral and later sided with Napoleon in his war against Britain. This in turn resulted in two vicious attacks on Copenhagen by the British (1801 and 1807), the hi-jacking of the Danish fleet and, eventually, the loss of Norway to Sweden as peace was made in 1814 .

17 See Petersen (1861), p. 131.

18 See Werlauff (1910), p. 121: “ingen af disse udgaver [i.e. Thorkelín's] kan udholde en nogenlunde stærk Kritik." ["none of his editions can stand up to much scrutiny"']. A more sympathetic view of Thorkelín's scholarly work appears in Wood (1972), pp. 74-96.
} 
New Testament into Icelandic (1807) were reviewed—and very unfavourably in both instances. ${ }^{19}$

This, and the openly displayed criticism of his work that emerges in books by Danish scholars such as E. C. Werlauff and N. M. Petersen, who were his contemporaries, can hardly have escaped Thorkelín's attention, because what they thought of his scholarly efforts would quite likely have been whispered in public long before their opinion found its way into their memoirs. To put it shortly, Thorkelín was being called an academic fraud long before his Beowulf edition appeared in 1815. ${ }^{20}$ And there was more. Decades after his death, Thorkelín's vanity, incompetence as an archivist and refusal to work with genuine scholars is said to have been remembered at the Royal Privy Archives. ${ }^{21}$

But Thorkelín was clearly an ambitious man, and criticism at home did nothing to deflate his ego. He freely bragged about being descended from Sæmundr fróði [=the Wise, 1056-1133] who was a leading literary scholar in Iceland during the Middle Ages ${ }^{22}$ and continued to convince others that he was just as great as this illustrious "ancestor." As Thorkelín's fast advancement in the world of scholarship in Denmark clearly shows, he was as good at impressing the right people with his abilities as he was at ingratiating himself to them. While in Britain, not only was he offered the above-mentioned position at the British Museum, but also made an Honorary Member of the Royal Irish Academy (1787), in Scotland an Honorary Doctor of Law at St. Andrews University (1788) and an Honorary Citizen of various Scottish cities. ${ }^{23}$ Not bad for an incompetent scholar.

Before we begin consider Thorkelín's editing work on Beowulf, one final aspect of his personality which affected that process needs to be considered. This is Thorkelín's great interest in money. During the 18th and the 19th centuries, most Icelandic scholars who worked in Copenhagen barely eked out a living, but that was not to be Thorkelín's lot. We have already seen how well he did for himself in financing his British venture, and yet, in his letters to Bülow, he often expresses his

\footnotetext{
19 Anon (1787) of the new Eyrbyggja saga edition cites various examples of unfounded assumptions and high-handed editing practices; then takes Thorkelín to task for numerous errors in the accompanying Latin translation and concludes by noting that on the whole, the edition is crawling with serious mistakes ["vrimler dette Værk overalt af meget anstødelige orthographiske og andre Fejl," p. 764]. As for the New Testament translation of 1807, a young theologian named Helgason reviewed it in 1808a and did not mince his words in respect to Thorkelín's scholarship. He had, said Helgason, ignored a wealth of material that was relevant to the new translation, and, in respect to language, Thorkelín was inconsistent in his spelling and his text full of language mistakes. All in all, the new translation was a great disservice to Iceland, because it only prolonged the wait for a usable text. This was more than Thorkelín (1808) could take, and he replied to Helgason in the appendix to the next issue of the journal. In short, he denied everything that Helgason accused him of but omitted to explain why the text of the translation seemed to confirm his criticisms. Helgason (1808b) replied in the next issue, brushed Thorkelín's arguments aside and re-affirmed his original objections.

${ }^{20}$ See e.g., Werlauff (1910), p. 121 where he compares Thorkelín as a scholar very unfavourably to other learned Icelanders (Jón Eiríksson, Skúli Thorlacius and Jón Ólafsson) in Copenhagen and Petersen's (1861), p. 131, where he describes Thorkelín as superficial, imprecise and untrustworthy ["mere efter det ydre Skin ... unøjagtig og upålidelig'’].

${ }^{21}$ See Jørgensen (1884), pp. 94-96.

${ }^{22}$ See Jørgensen (1884), p. 90 and Petersen (1861), p. 130.

${ }^{23}$ See Kristjánsson (1999), p. 30.
} 
annoyance over minor expenses of various kinds, ${ }^{24}$ and at the Royal Privy Archives, he kept complaining that his salary was too low. ${ }^{25}$ A turning point in Thorkelín's financial affairs was his marriage to a wealthy widow in 1792 . Her late husband had owned a brewery which Thorkelín now took over and continued to operate. At the same time he began to frequent auctions where he bought goods of all kinds which he then re-sold at a profit. This did not go unnoticed, and the venerable Keeper of the Royal Privy Archives became known in Copenhagen as the king of the rage-and-bone trade ("Marchandisernes Oldermand"). E. C. Werlauff, who supplies this information, then adds that as Thorkelín turned his attention to increasing his wealth, he abandoned nearly all scholarly work. ${ }^{26}$ A glance at Thorkelín's published works, indeed, verifies that between 1792 and 1807 he does not appear to have produced anything. And last but not least, Thorkelín was using money as an excuse for not having produced his long-awaited Beowulf edition 20 years after he discovered the manuscript. In a letter to Bülow from 1806, he complains that he cannot afford to go through the very expensive process of publishing an edition of a poem that only a few people will read. Of course Thorkelín is also indirectly asking his friend to finance the eventual publication of the poem which Bülow did. ${ }^{27}$

But now to Thorkelín's Beowulf edition. In 1815, when it finally appeared, 29 years had passed since he discovered the manuscript in the British Museum. This is a very long time, so long that something must be amiss, and yet most scholars who have commented on the edition have either ignored this time gap or shrugged it off. It also adds to this mystery that Thorkelín does not appear to have been in good health when he was making his own copy of the manuscript in 1787 or shortly thereafter, and, knowing as he did that he had found something very important, there was no time to lose in bringing out an edition. ${ }^{28}$ In their Beowulf-The Critical Heritage, T. A. Shippey and Andreas Haarder explain the long delay by suggesting that Thorkelín's editing work merely suffered the same fate as many other academic projects and had such an evident low priority because of his slow realization of what he had found. ${ }^{29}$ I think both these explanations are wrong. Academic projects are usually delayed by external factors such as lack of time or funds or other work that needs to be completed. In Thorkelín's case no such circumstances intervened, and, as I have already attempted to show, he was perfectly well aware of the importance of the Beowulf manuscript. It should also be emphasized that Thorkelín's stay in Britain had been very expensive, ${ }^{30}$ and that factor alone should have been putting additional pressure on him to justify his British venture by publishing the prize item that he had copied and brought back.

\footnotetext{
24 See Glahn (1925), pp. 54-62.

25 See Jørgensen (1884), p. 94.

26 See Werlauff (1910), p. 122.

27 See Christoffersen (1946), pp. 23-24.

28 Malone, in his study (1951), p. 22, notes what he calls Thorkelín's “'shaky hand.' Hall (1994), p. 245 takes this to indicate that Thorkelín's health "was probably not robust."

29 Shippey and Haarder (1998), p. 6.

30 Kristjánsson (1999), p. 31.
} 
T. A. Birrell has suggested that Thorkelín's marriage and his directorship of his brewery kept him from working on his Beowulf edition, ${ }^{31}$ but Birrell provides no evidence to back up this claim. Thorkelín himself offered various excuses as time went by. In the previously mentioned letter to Bülow from 1806 he complains about the difficulty of the work, particularly translating the Old English text, grumbles about the foreseeable cost of publishing his edition and the bleak prospect of attracting enough readers. Four years later he is still complaining to Bülow about the thankless task that he has undertaken. ${ }^{32}$

But by far the best excuse for the delay in the editing process was provided by the British navy when it bombarded Copenhagen in 1807. In the attack, Thorkelín's house burnt down and-according his preface to the Beowulf edition-his library, and with it his "rendering of the Scylding epic, together with its entire scholarly apparatus, perished utterly.', Only the two Beowulf transcripts survived. Had it not been for this catastrophe, Thorkelín adds, "[so] diligent was I that I would have finished the whole work in 1807." 33 It is of course a matter of opinion whether taking 20 years to produce an edition of the poem is a sign of much diligence, but the main question must be whether Thorkelín is being entirely truthful in his account. We only have his word for what actually happened, and not surprisingly, some scholars have expressed scepticism over his story. ${ }^{34}$ It must be said that it is rather difficult to picture Thorkelín having had time and opportunity to rescue his precious transcripts from the fire while his translation and editorial notes-presumably as close at hand and hardly very bulky — were left to be destroyed by the flames.

But by 1808 , the pressure on Thorkelín to complete his edition was mounting. In that year a work on Norse mythology (Nordens Mythologie) by a young Danish scholar, N. F. S. Grundtvig, appeared. Grundtvig announced Thorkelín's forthcoming Beowulf edition to his readers and expressed his hope that it would appear at the earliest opportunity and be a splendid monument to its maker. Neither of these wishes was to come true, and when the edition finally appeared in 1815, Grundtvig found it anything but splendid. ${ }^{35}$

As Shippey and Haarder have noted, Thorkelín's address to the reader in his edition betrays "certain uneasiness." 36 This is largely because for all his lamentation over the disaster that had befallen him in 1807, Thorkelín could not—or would not—offer any plausible justification for the very long delay in publication. Here I think lies a secret which he was not prepared to share with his readers; he had procrastinated so long because he was afraid. Two conflicting thoughts may well have played a tug-of-war in his mind. On the one hand, he must

\footnotetext{
31 See Birrell (1966), p. 112.

32 Christoffersen (1946), p. 23 and 25.

33 Bjork (1996), p. 309 and 311.

34 Werlauff (1910, p. 122) and Hall (1994, p. 250) fully accept Thorkelín's account while Christoffersen (1946, p. 25) believes that a letter from Thorkelín to Bülow in 1808 indicates that some papers survived, and Bjork and Kiernan are inclined not to believe Thorkelín's account-Kiernan calling it "a gross exaggeration.’' (See Bjork (1996), p. 295 and 295, n. 4).

35 See Christoffersen (1946), pp. 22-23.

36 Shippey and Haarder (1998), p. 12.
} 
have realized that being the first scholar to bring out an edition of the poem would attract attention far outside Denmark and bring him the kind of scholarly fame that he undoubtedly craved. On the other hand, he may also have had doubts that he was really up to the task of editing the poem-after all he had admitted to Bülow the difficulties he was having with it, and, as I noted earlier, Thorkelín had been stung with bad reviews of his work in the past. After all, if his edition were to meet with a bad reception, as indeed it did, fame would quickly be tainted by notoriety. So, what was he to do? For the better part of three decades, he does not seem to have been able to make up his mind until his hand was finally forced as word got out about his project.

Thorkelín's preface to his edition-his "Greetings to the Reader" —-sums up his conclusions about the poem. Predictably, he seeks to make it Danish in all respects, and at the same time, sing the praises of Danish kings and heroes. Thorkelín argues that Beowulf is originally a pagan Danish poem, composed by a poet who was an eyewitness to the heroic exploits of Hroðgar, Hygelac and Beowulf. Beowulf died in Jutland in AD 340, ${ }^{37}$ and was eulogized by our Danish poet at his funeral. In all likelihood the poem had then found its way to England during the reign of Alfred the Great who had had it translated into the Anglo-Saxon dialect of Old Norse, ${ }^{38}$ and it was under his auspices that the Christian elements had been interpolated into the poem. About the only mystery that Thorkelín admitted that he could not solve was the identity of the poet - a rare concession in a preface that almost entirely rested on linguistic naiveté, unfounded speculation and flights of fancy couched in his usual pompous classicism. ${ }^{39}$

But emphasis on plain nationalism was not enough for Thorkelín. The poem offered a great opportunity to pay tribute to the virtues of the monarchy and the glory of Danish kings - past and present_and he had no qualms about exploiting this chance, even if it meant distorting the text of the poem. T. A. Shippey and Andreas Haarder have described Thorkelín's royal bias in his Beowulf edition as follows:

His lengthy encomia on Hrothgar and Hygelac, almost without basis in his text (he capitalises the name 'Hrothgar' every time it appears in his 'Address') are statements about the virtues of monarchy-obviously relevant as Europe was trying to settle down once more in the very last year of the Napoleonic warsand about the unity of Denmark, island Danes and peninsular Jutes combined: Hrothgar's alleged granting of 'citizenship' to the Jutish plebs and senatorial status to their nobles does not come from the poem but from King Frederik VI's

\footnotetext{
37 Thorkelín came to this remarkable conclusion about the dating of events described in the poem by following his friend's Peter Suhm's Geschichte der Dänen in which Suhm insisted that Odin's son, Boe, had died in battle in AD 340. Thorkelín then readily identified Boe with Beowulf.

38 This fallacy was to lead Thorkelín to overconfidence regarding the semantic affinity of Old English and Old Norse and generate many of his mistaken readings of the text of the manuscript. However, he was far from being alone in believing in this linguistic kinship, which was first suggested during the 18th century and continued to be argued well into the 19th. As Robert Bjork puts it: "The notion that the Anglo-Saxons spoke a Danish dialect became lodged in the Danish national consciousness for at least 100 years.' 'For further discussion, see Bjork (1996), p. 293 and Shippey and Haarder (1998), pp. 10-11.

39 For the full text of Thorkelín's preface in an English translation see Bjork (1996), pp. 299-317.
} 
contemporaneous attempts to win the loyalty of Schleswig-Holstein and especially of its troublesome Ritterschaft [=assembly of noblemen]. ${ }^{40}$

Thorkelín, it might be added, reads the poem to mean that all northern tribes were called Danes (East-, West-, South- and North-), ${ }^{41}$ and as a result, his rendering of events becomes for the most part a tale of internal strife among the great Danish nation.

Old habits die hard, and again Thorkelín managed to combine his obsession with Danish kings with a rather clumsy attempt to pay tribute to the political wisdom of Frederik VI, and it goes without saying what this reading of the poem was meant to achieve.

In the years between 1815 and 1818 Thorkelín's edition received seven reviews; one English, two German, one Swedish and three Danish which taken together testify to "the immediately negative reception of his work," as Robert Bjork has put it. ${ }^{42}$ These reviews vary greatly in quality, as some of them actually make claims even more far-fetched than Thorkelín's. Still, four of these early reviewers (Penzel, Bouterwek, Gumælius and Müller) rejected out of hand the claim that the poet had been an eyewitness to Beowulf's funeral in $\mathrm{AD} 340,{ }^{43}$ and by doing so demolished much of Thorkelín's general historical setting. One of the Danish reviewers, P. E. Müller, also attacked Thorkelín's linguistic premise by arguing that the language of Beowulf was not like Icelandic at all. ${ }^{44}$

But by far the most damaging (and abusive) criticism came from Grundtvig. In his initial review in 1815, Grundtvig attacked Thorkelín for what he claimed to be a host of mistakes both in the Old English text and the Latin translation. The first section of the poem was, for instance, completely mangled in Thorkelín's edition, as Grundtvig showed that it described not a Viking raid but a funeral. Grundtvig's other major grievance was Thorkelín's consistent inability to recognize proper names - thereby, of course, throwing his already distorted interpretation of the poem further into the abyss. Thorkelín replied to Grundtvig's review and chose to deny all charges and challenged Grundtvig to come up with a better translation of the poem. Grundtvig did just that in 1820 and sensibly departed from Thorkelín's convoluted title to simply name the poem after its main hero. But in the meantime, in 1817 , he followed up his 1815 review with a very long article in which he carefully polished and re-stated his original criticisms of Thorkelín's edition. In addition, he identified Hygelac with a certain Chochilaicus mentioned by Gregory of Tours in his Historia Francorum, and in doing so provided a firm framework for the dating of events within the poem, as well as burying Thorkelín's ideas on the subject once and for all. ${ }^{45}$

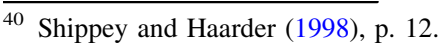

${ }^{41}$ For Thorkelín's translation of the poem, see e.g., Cooley (1940), pp. 47-51.

42 Bjork (1996), p. 294.

${ }^{43}$ Shippey and Haarder (1998), pp. 14 and 20.

${ }^{44}$ Shippey and Haarder (1998), pp. 20-21.

${ }^{45}$ See Shippey and Haarder (1998), pp. 10-26, 108-116 and 143-152 and Christoffersen (1946), pp. 28-32.
} 
Further evidence of Thorkelín's incompetence was brought to light by John Conybeare's study of his edition (published posthumously in 1826) which showed hundreds of hitherto undiscovered gaffes in Thorkelín's text. John Kemble's new edition of the poem, which appeared in 1833, was, in a manner of speaking, the final nail in Thorkelín's editorial coffin, as Kemble delivered a thundering verdict of his predecessor's work in his prologue: 'not five lines of Thorkelin's edition can be found in succession, in which some gross fault either in the transcript or the translation, does not betray the editor's utter ignorance of the Anglo-Saxon language.',46

Thorkelín was spared this last humiliation as he died in 1829. There is, however, sufficient evidence to show that his remaining years following the publication of the Beowulf edition were a time of misery and monumental disappointment. ${ }^{47}$ But from what we know about Thorkelín's life and scholarship, there was nothing unexpected about the fate of his Beowulf edition. He had shown himself to be gullible and naive in his earlier work, and he had more than once been accused of sloppy workmanship. When these scholarly shortcomings are added to personal ideosyncrasies such as his obsession with Danish kings and the need to ingratiate himself with them through flattery, it cannot be said that the 1815 edition contains many surprises. All his life, Grímur Thorkelín had created the illusion of being a much greater scholar than he actually was, and he had lived this lie quite successfully, but now it caught up with him. In John Webster's play: The Duchess of Malfi, Ferdinand wonders in his dying speech at what brings a man to ruin: "whether we fall by ambition, blood, or lust" (Act V, Scene V, 1. 72). In Grímur Thorkelín's case, he did the scholarly world a service by putting Beowulf on the literary map-however bad his edition. But in doing so, his ambition laid bare all the shortcomings that he had so far managed so well to hide.

\section{References}

Anon (1787). Review of Thorkelín's edition of Eyrbyggja saga. Nyeste Kjфbenhavnske Efterretninger om larde Sager for 1787. 48, 753-764.

Birrell, T. A. (1966). The society of antiquaries and the taste for old English 1705-1840. Neophilologus, 50, 107-117.

Bjork, R. (1996). Grímur Jónsson Thorkelin's preface to the first edition of Beowulf, 1815. Scandinavian Studies, 68, 291-320.

Christoffersen, J. (1946). Hvorledes Beowulf kom til Danmark. Bogvennen, 2, 19-33.

Cooley, F. (1940). Early Danish criticism of Beowulf. English Literary History, 7, 45-67.

Glahn, A. (1925). Mæcen og Klient—av en brevveksling mellem to bogvenner, 1785-1790. Aarbog for bogvenner, 9, 49-94.

\footnotetext{
$\overline{46}$ Quoted from Bjork (1996), p. 291.

47 Christoffersen (1946): "Havde Thorkelin troet at hans Genvordigheder var forbi, nu da hans Værk forelaa oversat og trykt, saa mødte ham ogsaa her en alvorlig Skuffelse, ja vel hans Livs største, som egentlig i Aarevis prægede ham og nedslog hans Livsmod.' ["If Thorkelín had thought that his troubles were over now that his edition was translated and published, he was in for a serious disappointment, the greatest that had to face during his lifetime, and one that for years would take its toll and depress his spirits.', ], p. 29.
} 
Hall, J. R. (1994). The first two editions of Beowulf: Thorkelin's (1815) and Kemble's (1833). In: D. G. Scragg \& P. E. Szarmach (Eds.), The editing of old English-papers from the 1990 Manchester Conference (pp. 239-250). Woodbridge: D. S. Brewer.

Helgason, Á. (1808a). Review of Thorkelín's new testament translation from 1807. Kjøbenhavnske larde Efterretninger, 31, 491-494.

Helgason, Á. (1808b). Recensentens Svar paa Antikritiken i Tillagget til larde Efterretninger, 170, 32. Kjфbenhavnske larde Efterretningar, 33, 525-528.

Jørgensen, A. D. (1884). Udsigt over de danske Rigsarkivers historie. Copenhagen: De under Kirke- og Undervisningsministeriet samlede arkiver.

Kiernan, K. S. (1995). The legacy of Wiglaf. In: P. S. Baker (Ed.), Beowulf-basic readings (pp. 195218). New York: Garland Publishing.

Kristjánsson, A. (1999). Nú heilsar pér á Hafnarslóð. Reykjavík: Nýja bókafélagið.

Malone, K. (1951). The Thorkelin transcripts of Beowulf in facsimile. Copenhagen: Rosenkilde and Bagger.

Ólason, P. E. (1949). Íslenzkar aeviskrár frá landnámstímum til ársloka 1940, Vol. II. Reykjavík: Hið íslenzka bókmenntafélag.

Petersen, N. M. (1861). Bidrag til den danske literaturs historie i oplysningens tidsalder, 1750-1800. Copenhagen: Berlinske bogtrykkeri.

Shippey, T. A., \& Haarder, A. (Eds.) (1998). Beowulf-the critical heritage. London: Routledge.

Thorkelín, G. (1788). Fragments of English and Irish history in the ninth and the tenth century, in two parts, translated from the original Icelandic, and illustrated with some notes. London: Printed by and for John Nichols.

Thorkelín G. (1791). Sketch of the character of his Royal Highness the Prince of Denmark to which is added a short review of the present state of literature and the polite arts in that country; interspersed with anecdotes/in four letters by a gentleman long resident in Copenhagen to a friend in London. London: J. Ridgway.

Thorkelín, G. (1808). Svar paa hr. pastor Helgesens recension af det nye Testamente paa Island. Tillaeg til Kjфbenhavnske larde Efterretninger, 32, 1-16.

Werlauff, E. C. (1910). Erindringer af mit liv. Copenhagen: Gyldendalske boghandel.

Wood, E. H. H. (1972). Letters to an antiquary-the literary correspondence of G. J. Thorkelin (1752-1829). Unpublished $\mathrm{PhD}$ thesis. Edinburgh: Edinburgh University. 